\title{
UDK 636.5.087.7
}

E.V. SYVACHENKO, Applicant for a degree,

L.S. DYACHENKO, Doctor of Agricultural Sciences, Professor,

Bila Tserkva National Agrarian University

E-mail: djachenko@hotmail.com

\section{Performance in broiler chickens under introduction of the acidifiers to the diet}

\begin{abstract}
In recent years, poultry meat production in Ukraine has increased. The main place belongs to broiler meat. Recent alternatives include known probiotics, prebiotics, enzymes, mananooligosaccharides, antioxidants, tranquilizers, bacteriostatics etc. This list we you can add Acidifiers which are composed of various acids and their salts to support increased acidity in the stomach, which contributes to the release of stomach juice and pancreatic enzymes. This, in turn, improves digestion and assimilation of nutrients.

The purpose of the study is to investigate the effect of different doses Acidifier "FRA LBB DRY" in the fodder on productivity of broiler chickens.

The experiments were carried out in vivarium of Bila Tserkva national agrarian university. Three analog groups of broiler chickens cross "Cobb-500" were formed at age of 3 days with 46 birds in each group. The first (control) group of broilers was fed with balanced complete feed according to the norms corresponding to age periods of growth. Chickens of the 2nd experimental group were fed with full-feed with addition of acidifier "FRA LBB DRY", at a dose of $3 \mathrm{~kg} /$ ton of feed, chickens of the 3 rd experimental group received full-feed with addition of the acidifier at dose of $5 \mathrm{~kg} / \mathrm{t}$ of feed.

The addition of the acidifier to the feed had positive influence on survival of chicken broilers. In both experimental groups this index was higher than in control by $4.3 \%$.

The weight of chickens of the 2 nd and the 3rd experimental groups at 42-day age was respectively 2409.4 and $2411.9 \mathrm{~g}$ vs. $2295.4 \mathrm{~g}$ in control. The total body weight increase was statically higher in experimental groups by 113,4-117.6 $\mathrm{g}$ and the cost of feed for $1 \mathrm{~kg}$ of growth was smaller than the control by $3.4 \%$.

The most objective indicator of economic evaluation of growing broiler chickens is the European index of efficiency, which in the experimental groups higher by 37.8-38.6 units than in control.
\end{abstract}

Key words: broiler chickens, acidifier, performance, weight of chickens

$\mathrm{n}$ recent years, poultry meat production in Ukraine has increased. The main place belongs to broiler meat. The scientists are constantly searching for new more efficient feed components to replace those that have exhausted their biological potential, or is not desirable in poultry diets, such as antibiotics. Recent alternatives include known probiotics, prebiotics, enzymes, mananooligosaccharides, stimulators, antioxidants, tranquilizers, bacteriostatics etc. (Okolelova et al., 2010; Svezhentsov, 2004).

A number of studies were conducted in the past decade on the efficiency of acidifiers (organic acids) in feeding animals and birds. Studies have shown that organic acids promote the development of desirable micro-biota in the gastrointestinal tract of the chicks starting from the beginning of its life, thereby cleansing the digestive system off from E. colli, Salmonella, Campylobacter and more. A characteristic feature of organic acids as lipophilic substances is their ability to easily penetrate the bacterial cell membrane and the cytoplasm executing antimicrobial activity inside cells. And for long-term use of organic acids in the feed to them can adapt any bacteria (Kotsyumbas et al., 2013).

According to the results of studies of foreign authors (Samudovska and Demeterova, 2010; et al., Abdel-Fattah, 2008), the use of organic acids in feeding improves digestibility and absorption of nutrients, increases productivity and reduces the cost of animal feed.

Proven is also neurotropic and antioxidant effect of organic acids in animals and its normalizing effect on energy metabolism, biosynthesis and overall physiological state (Kozinets et al., 2013).

Even more progressive now are the feed acidifiers consisting of complexes of synergistic combinations of mono-, di-and triglycerides of fatty acids, which have much stronger properties than other Acidifiers, and can operate 


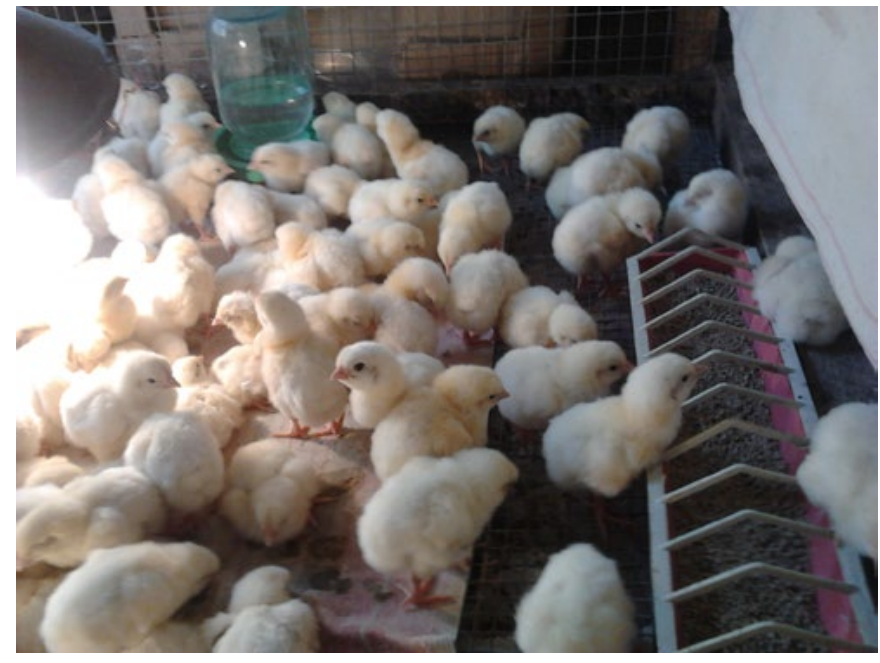

regardless of $\mathrm{pH}$ throughout all the gastrointestinal tract of poultry. One of these drugs is the acidifier "FRA LBB DRY" from Danish company "Vudhoff."

The acidifiers exhibit multi-vector action in different parts of the digestive tract of animals at different $\mathrm{pH}$ values. To enhance the transformation of nutrients in feed products, it is very important to determine the optimal doses of these additive for specific species, sex, age, physiological status and productivity of animals and birds, including broiler chickens,

The purpose of the study is to investigate the effect of different doses Acidifier "FRA LBB DRY" in the fodder on productivity and morphological and biochemical blood parameters of broiler chickens.

Methods. The experiments were carried out in vivarium of Bila Tserkva national agrarian university. Three analog groups of broiler chickens cross "Cobb-500" were formed at age of 3 days with 46 birds in each group.

The first (control) group of broilers was fed with balanced complete feed according to the norms corresponding to age periods of growth. Chickens of the 2nd experimental group were fed with full-feed with addition of acidifier "FRA LBB DRY", at a dose of $3 \mathrm{~kg} /$ ton of feed, chickens of the $3 \mathrm{rd}$ experimental group received full-feed with addition of the acidifier at dose of $5 \mathrm{~kg} / \mathrm{t}$ of feed.

Birds of all groups had free access to food. Nipple watering system was used to provide drinking water. The duration of daylight was 24 hours, with the light intensity of 5 lux. The room temperature was within the normal range throughout the period of the experiment.

Following data was recorded during the experiment: the safety of livestock broiler chickens, consumption of feed and its cost per $1 \mathrm{~kg}$ of growth, average daily live weight, the European index of efficiency of production. Additionally, morphological and biochemical parameters of blood were recorded. Blood was collected and analyzed according to the established protocols (Levchenko, 2004).

The results were subjected to biometric processing by conventional methods (Kulikov and Nikishov, 2006).

Results and discussion. The addition of the acidifier to the feed at doses 3 and $5 \mathrm{~kg} / \mathrm{t}$ had undoubtedly positive influence on survival of chicken broilers (table). In both experimental groups this index was higher than in control by $4.3 \%$. This can be attributed to lowering pathogenic micro-biota by action of the acidifier.

The protective effect of the acidifier positively affected the growth intensity of broiler chickens. The average daily weight gain during the experimental period in control broiler chickens was $53.5 \mathrm{~g}$. The peers in their $2 \mathrm{nd}$ and $3 \mathrm{rd}$

\section{Results of the scientific and economic experiment on broilers}

\begin{tabular}{|c|c|c|c|}
\hline \multirow{2}{*}{ Indicator } & \multicolumn{3}{|c|}{ Group } \\
\hline & $\begin{array}{c}1 \\
\text { (control) }\end{array}$ & $\begin{array}{c}\text { II } \\
\text { (experimental) }\end{array}$ & $\begin{array}{c}\text { III } \\
\text { (experimental) }\end{array}$ \\
\hline Livestock survival, \% & 93.5 & 97.8 & 97.8 \\
\hline $\begin{array}{l}\text { Body weight of chickens, g: } \\
\text { at the beginning of the experiment }\end{array}$ & 48.4 & 49.0 & 47.3 \\
\hline $\begin{array}{l}\text { Body weight of chickens at age } 42 \text { days } \\
\text { (end of experiment), } g(M+m, n=46)\end{array}$ & $2295.4 \pm 27.6$ & $2409.4 \pm 27.5^{* *}$ & $2411.9 \pm 27.8^{* *}$ \\
\hline The total increase, $g(M+m, n=46)$, & $2247.0 \pm 27.9$ & $2360.4 \pm 29.3^{* *}$ & $2364.6 \pm 17.3^{* *}$ \\
\hline $\begin{array}{l}\text { The average increase in body weight during the experiment, } g \\
\qquad(M+m, n=46)\end{array}$ & $53.5 \pm 0.87$ & $56.2 \pm 0.74 *$ & $56.3 \pm 0.49 * *$ \\
\hline In $100 \%$ to the control & 100 & 105.0 & 105.2 \\
\hline Acidifiers consumed by 42 days, $g /$ head & 0 & 12.6 & 21.0 \\
\hline Feed consumed during experiment, g/head & 4067.1 & 4137.0 & 4138.0 \\
\hline The costs of feed for $1 \mathrm{~kg}$ of growth, $\mathrm{kg}$ & 1.81 & 1.75 & 1.75 \\
\hline European efficiency index & 282.3 & 320.1 & 320.9 \\
\hline
\end{tabular}

Note: ${ }^{*}-P<0.05,{ }^{*}-P<0.01$. 


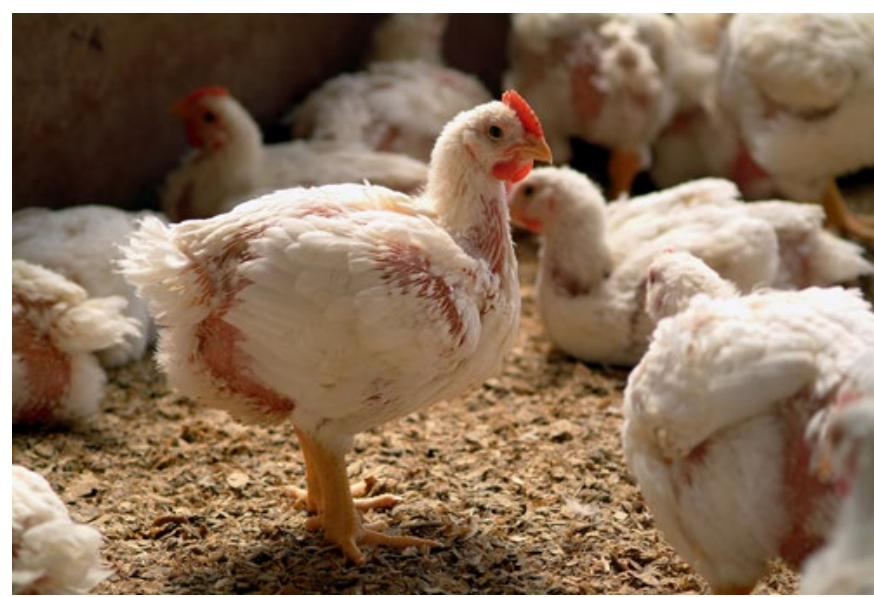

experimental group demonstrated higher growth intensity by 5.0 and $5.2 \%(P<0.05$ and $P<0.01)$. The same is true for live weight of chickens at the end of the experiment and the total (absolute) increase in body weight, which are directly related to the average daily gain. In particular, the weight of chickens of the 2 nd and the 3rd experimental groups at 42-day age was respectively 2409.4 and $2411.9 \mathrm{~g}$ vs. $2295.4 \mathrm{~g}$ in control. The total body weight increase was statically higher in experimental groups by $113,4-117,6 \mathrm{~g}$ $(P<0.01)$, and the cost of feed for $1 \mathrm{~kg}$ of growth was smaller than the control by $3.4 \%$.

The most objective indicator of economic evaluation of growing broiler chickens is the European index of efficiency, which in the experimental groups higher by 37,8-38,6 units than in control.

We previously published data on morphological and biochemical parameters of blood in broiler chickens under introduction of the acidifiers to the diet (Syvachenko et al., 2016).

Therefore, the analysis of the morphological and biochemical parameters of blood indicates mainly positive impact of the acidifier on protein, carbohydrate, fat and mineral metabolism and some enzyme The status of the body of broiler chickens. This in turn contributed to increasing their productivity. Out of two investigated doses of the acidifier ( 3 and $5 \mathrm{~kg} / \mathrm{t}$ of feed) the higher dose did not provide significantly higher benefits, so the suggested dose of the acidifier "FRA LBB DRY" for broiler chickens can be considered $3 \mathrm{~kg} / \mathrm{t}$ of feed.

\section{Conclusions}

1. Feeding broiler chickens with the feed supplemented with the acidifier "FRA LBB DRY" at doses of 3 and $5 \mathrm{~kg} / \mathrm{t}$ improved survival of flock by $4.3 \%$, average daily gain by $5,0-5,2 \%$; reduce feed costs by $3.4 \%$ and increased efficiency of European index of rearing by 37,6-38,8 units.

1. According to current assessment of the results, the optimal dose of the acidifier "FRA LBB DRY" for broiler chickens can be considered $3 \mathrm{~kg} / \mathrm{t}$ of feed.

Prospect for the future research is to investigate the efficiency of the acidifier "FRA LBB DRY" in liquid form with drinking water and reduce its cost in diets of broiler chickens.
Є.В. СИВАЧЕНКО, зgобувач,

Л.С. ДЬЯЧЕНКО, gоктор сільськогоспоgарських наук, професор,

Білоцерківський національний аграрний університет

E-mail:djachenko@hotmail.com

\section{Продуктивність курчат- бройлерів за згодовування підкислювача}

Анотація. Останнім часом виробництво м'яса птиці в Україні зростає. При цьому основна частка припадає на м'ясо курчат-бройлерів. Учені постійно вишукують нові препарати для підвищення продуктивності бройлерів. Наразі до альтернативних засобів належать відомі пробіотики, пребіотики, ферменти, мананоолігосахариди, антиоксиданти, транквілізатори, бактеріостатики тощо. До цього переліку можна додати ще й підкислювачі, які у своєму складі можуть мати різноманітні кислоти та їх солі, завдяки чому підтримується підвищена кислотність у шлунку, що сприяє більшому виділенню соку та ферментів підшлункової залози.

Мета досліджень-вивчити вплив різних доз підкислювача "FRA LBB DRY" в комбікормі на продуктивність курчат-бройлерів. Дослідження проводили у віварії Білоцерківського національного аграрного університету. Методом груп-аналогів у добовому вічі було сформовано 3 групи курчат-бройлерів кросу "Кобб-500". Першу (контрольну) групу курчат-бройлерів годували збалансованими повнораціонними комбікормами відповідно до норм згідно з віковими періодами вирощування. Курчатам 2-ї оослідної групи до повнораціонного комбікорму додавали підкислювач "FRA LBB DRY", який складається із синергічного поєднання комбінацій моногліцеридів пропіонової, масляної та лауринової кислот, у дозі 3 кг/m комбікорму Курчатам 3-ї дослідної групи до повнораціонного комбікорму додавали підкислювач у дозі 5 кг/m комбікорму. Додавання підкислювача до корму позитивно вплинуло на збереженість курчат-бройлерів. В обох експериментальних групах цей показник був вищим, ніж у контрольних, на 4,3\%. Захисна дія підкислювача позитивно позначилася і на інтенсивності росту курчатбройлерів. При цьому, жива маса курчат 2- і 3-ї дослідних груп у 42 добовому віці становила, відповідно, 2409, 4 і 2411, 9 г проти 2295, 4 г у контролі, абсолютний приріст живої маси перевищував контрольну птицю на 113, 4-117, 6 2, при цьому витрати корму на 1 кг приросту у них були менші за контроль на $3,4 \%$. 
Європейський індекс ефективності у дослідних групах на 37, 8-38, 6 одиниці вищий, ніж у контролі.

Ключові слова: курчата-бройлери, підкислювач, продуктивність, маса курчат

\section{Е.В. Сиваченко, Л.С. Дьяченко}

\section{Продуктивность цыплят- бройлеров при скармливании подкислителя}

Аннотация. В последнее время производство

мяса птицы в Украине растет. При

этом основная доля приходится на мясо

цыплят-бройлеров. Ученые постоянно

изыскивают новые препараты для повышения производительности бройлеров. Сейчаск альтернативным средствам относятся пробиотики, пребиотики, ферменты, мананоолигосахариды, антиоксиданты, транквилизаторы, бактериостатики и m.д. К этому перечню можно добавить еще и подкислители, которые в своем составе могут иметь различные кислоты и их соли, благодаря чему поддерживается повышенная кислотность в желудке, что способствует большему выделению сока и ферментов поджелудочной железы.

Цель исследований - изучить влияние различных доз подкислителя "FRA LBB DRY" в комбикорме на продуктивность цыплятбройлеров.

Исследования проводили в виварии

Белоцерковского национального аграрного университета. Методом групn-аналогов в суточном возрасте было сформировано 3 группы цыплят-бройлеров кросса "Кобб500". Первую (контрольную) группу цыплятбройлеров кормили сбалансированными полнорационные комбикорма соответствии с нормами согласно возрастным периодам выращивания. Цыплятам 2-й опытной группы к полнорационному комбикорму добавляли подкислитель "FRA LBB DRY", который состоит из синергического сочетание комбинаций моноглицеридов пропионовой, масляной и лауриновой кислот в дозе 3 кг/т комбикорма, цыплятам 3-й опытной группы к полнорационного комбикорма добавляли подкислитель в дозе 5 кг/m комбикорма. Добавление подкислителя в корм положительно повлияло на сохранность цыплят-бройлеров. В обеих экспериментальных группах этот показатель был выше, чем в контрольной, на 4,3\%. Защитное действие подкислителя положительно сказалась и на интенсивности роста цыплят-бройлеров. При этом, живая масса цыплят 2-й и 3-й опытных групп в 42-суточном возрасте составляла, соответственно, 2409, 4 и 2411, 9 г против 2295, 4 г в контроле, абсолютный прирост живой массы превышал контрольную птицу на 113,4- 117, 6 2, при этом затраты корма на 1 кг прироста у них были меньше контроля на 3,4\%. Европейский индекс эффективности в опытных групnах на 37, 8-38, 6 единиц выше, чем в контроле.

Ключевые слова: цыплята-бройлеры, подкислитель, продуктивность, масса цыплят

\section{References}

Abdel-Fattah, S.A., El-Sanhoury, M.H., El-Mednay, N.M. and Abdel-Azeem, F. (2008). Thyroid Activity, Some Blood Constituents, Organs Morphology and Performance of Broiler Chicks Fed Supplemental Organic Acids. International Journal of Poultry Science. 7 (3). 215-222.

Kotsiumbas, I.Ya., Hunchak, V.M., Stetsko, T.I. (2013). Problemy vykorystannia antymikrobnykh preparativ dlia stymuliuvannia rostu produktyvnykh tvaryn ta alternatyvy yikh zastosuvanniu [Problems of antimicrobial agents to stimulate growth of farm animals and the use of alternative]. Naukovotekhnichnyi biuleten Instytutu biolohii tvaryn i Derzhavnoho naukovo-doslidnoho kontrolnoho instytutu vetpreparativ ta kormovykh dobavok [Scientific and Technical Bulletin of the Institute of Animal Biology and State research control institute of veterinary preparations and feed additives. 14. 3-4. 381-389. Kozinets, A.I., Holushko, O.G., Nadarynskaya, M.A., Kozinets, T.G. (2013). Podkyslytel "Kyskad" v kormlenyy molodniaka krupnoho rohatoho skota [Acidifier "Kyskad" in feeding of young animals of large horned livestock [electronic resource]. Naukovyi visnyk Natsionalnoho universytetu bioresursiv $i$ pryrodokorystuvannia Ukrainy [Scientific Journal of NULES of Ukraine]. 190. 110-114. URL: http://nbuv.gov.ua/j-pdf/Ntbibt_2013_14_3-4_71. pdf.

Kulikov, L.V., Nikishov, A.A. (2006). Matematycheskoe obespechenye эksperymenta $v$ zhyvotnovodstve (2-e yzdanye) [Mathematical Provision of experiments in animal husbandry (2nd edition)]. M. Publishing House of Friendship University. 178.

Levchenko, V.I., Novozhytska, Yu.M., Sakhniuk, V.V., Tyshkivskyi, M.Ya., Holovakha, V.I., Moskalenko, V.P., Vovkotrub, N.V., Rozumniuk, A.V., Holub, O.Yu., Tbshkivska, N.V., Slivinska, L.H., Fasolia, V.I. (2004). Biokhimichni metody doslidzhennia krovi tvaryn: metodychni rekomendatsii [Biochemical methods of animal blood: Guidelines]. Kyiv. 110.

Okolelova, T.M. Kuznietsov, A.S., Savchenko, V.S. (2010). Preparat Formy v kombykormakh dlia broilerov [Drug forms in feed for broilers]. Efektyvne ptakhivnytstvo [Efficient poultry]. 4. 37-39.

Samudovska, A., Demeterova, M. (2010). Effect of water acidification on performance, carcass characteristic and some variables of intermediary metabolism in chickens. Acta Veterinaria (Beograd). 60. 4. 363-370.

Syvachenko, E., Dyachenko, L., Syvuk, T.I. (2016). Performance, morphological and biochemical parameters of blood in broiler chickens under introduction of the acidifiers to the diet. Suchasne ptakhivnytstvo [Modern Poultry]. 2016. 9-10. 37-40.

Svezhentsov, A.I. (2004). Netraditsionnyie kormovyie dobavki dlya zhivotnyih i ptitsyi [Untraditional feed supplements for animals and poultry]. Dnepropetrovsk: Art Press. 296. 